\title{
APLIKASI MATLAB DALAM MENGUKUR KEBULATAN HASIL INDENTASI UJI KEKERASAN BAGI KARYAWAN PT. SRI TERANG LINGGA PALEMBANG
}

\author{
Irawan Malik $^{1)}$, Moch. Yunus ${ }^{2)}$, Soegeng Witjahjo ${ }^{3)}$, Romli $^{4)}$

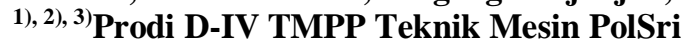 \\ irawanmalik@yahoo.com, myunuspolsri@gmail.com, switjahjo16@gmail.com \\ 4)Teknik Mesin PolSri \\ romli@polsri.ac.id
}

\begin{abstract}
Provision of spare parts for production equipment needs to be prepared with specifications, number of needs and correct time of availability, and especially for critical machining components that require correct and appropriate tactics so as not to disrupt its continuity of production. However, it is not a secret for a production department to make replacement parts that have the same mechanical properties through hardness testing of components that have failed. Through a computer program with an algorithm that is able to read a photo as a result of an indentation emphasis on hardness test, it can be known quickly a roundness diameter and calculate its hardness value which will be converted into one of the mechanical properties of a material so that a profile projector is not needed. Core of this implementation of our community service program is through an assignment scheme for employees of PT. Sri Trang Lingga Palembang, located on road TPA 2, RT. 26, RW. 29, Keramasan Subdistrict, Kertapati, Palembang City, South Sumatra, postal code 30149 is how to provide theoretical and experimental knowledge of the implementation of hardness tests on metal materials by emphasizing use of computer algorithms in reading photos of indentation hardness test results as an alternative to replacement use profile projector tool that is usually used for students of D-IV Mechanical Engineering Production and Maintenance (TMPP) Department of Mechanical Engineering Sriwijaya State Polytechnic to determine size of the indentation diameter emphasis from Brinnel hardness test.
\end{abstract}

\section{Keywords: Program Pengabdian, Matlab, Identasi, Uji Kekerasan, Brinnel}

\section{PENDAHULUAN}

Material logam pada keadaan tertentu sebelum digunakan perlu mengalami pengujian antara lain uji tarik, uji kekerasan, uji metalografi dan lain-sebagainya, dengan maksud dan tujuan umumnya untuk mengetahui sifat-sifat utama dari material tersebut, baik dari segi kekuatannya, ketahanan maupun sifat-sifat yang lain terhadap suatu beban yang akan diberikan.

Dengan kondisi di atas maka staf program studi D-IV Teknik Mesin Produksi dan Perawatan (TMPP) jurusan Teknik Mesin Politeknik Negeri Sriwijaya telah berhasil memberikan pelatihan dalam bentuk kegiatan pengabdian kepada masyarakat industri yaitu "Pelatihan Pemanfaatan Program Komputer untuk Mendapatkan Diameter Indentor Hasil Uji Kekerasan Bagi Karyawan PT. Sri Trang Lingga Palembang" yang berlokasi di jalan TPA 2,RT.26, RW. 29, Kecamatan Keramasan, Kertapati, Palembang, Sumatera Selatan, kode pos 30149.
Melalui program komputer dengan algoritma yang mampu membaca suatu foto hasil dari penekanan indentor uji kekerasan pada suatu komponen maka dapat diketahui dengan cepat diameter kebulatannya dengan tepat (tanpa menggunakan alat profile projector misalnya) dan menghitung nilai kekerasannya yang akan dikonversikan menjadi salah satu nilai sifat mekanik suatu material.

\section{IDENTIFIKASI MASALAH}

Aspek produksi memerlukan penggantian yang tepat dan cepat dari suku cadang material besi/baja yang jika dipesan dari vendor atau pihak manufaktur akan memakan waktu yang lama dan biaya yang relatif lebih tinggi.

Dengan demikian muncul permasalahan bagi mitra berupa cara tepat dan cepat untuk mengetahui sifat mekanik dari material suku cadang yang akan diganti melalui uji kekerasan dan bagi akademisi berupa langkahlangkah terstruktur dalam menyampaikan 
pengetahuan tentang teori kekerasan suatu material, langkah-langkah dalam menyampaikan pengetahuan dan ketrampilan melaksanakan uji kekerasan suatu material di suatu alat uji kekerasan, dan teknik dalam mengukur diameter hasil penekanan indentor dengan tepat dan mudah tanpa menggunakan alat profil proyektor.

\section{METODOLOGI PELAKSANAAN}

Pelaksanaan kegiatan pengabdian kepada masyarakat ini dilaksanakan dalam rangkaian mengikuti alur pada gambar 1 secara teoritis dan eksperimen sebagai berikut:

- Melaksanakan observasi ke lokasi dan diskusi dengan pimpinan PT. Sri Trang Lingga di Palembang

- Menyiapkan alat, bahan dan materi yang diperlukan untuk pelatihan program pengabdian

- Pelaksanaan pelatihan di laboratorium Mekanik Teknik Mesin Politeknik Negeri Sriwijaya atau di PT. Sri Trang Lingga Palembang

- Penyusunan laporan sesuai kegiatan yang telah dilaksanakan

- Evaluasi kegiatan.

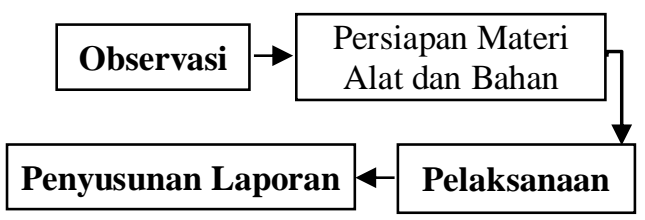

Gambar 1. Metodologi PKMSP

\section{HASIL DAN PEMBAHASAN}

Hasil dari kegiatan Program Pengabdian Kepada Masyarakat Skim Penugasan (PKMSP) bersama karyawan PT. Sri Trang Lingga Palembang disarikan pada tabel 1 yang mendeskripsikan urutan teoritis dan ketrampilan pengujian kekerasan Brinell dan tabel 2 menunjukkan hasil ujian pre-test dan post-test tujuh peserta, dan gambar 2 menampilkan sebagian foto-foto kegiatan pengabdian seperti proses pengujian kekerasan Brinell, demonstrasi pengukuran diameter indentasi baik menggunakan proyektor profil maupun dengan algoritma program Matlab $^{\odot}$ dan potongan skrip program program Matlab $^{\odot}$.

Kegiatan efektif PKMSP dilaksanakan dalam bentuk ceramah - tanya jawab, demonstrasi praktik dan uji kompetensi keduanya selama empat hari berturut-turut.

\section{KESIMPULAN}

Proses pelatihan pengukuran diameter indentasi hasil uji kekerasan menggunakan metode pengukuran kekerasan Brinell untuk beberapa karyawan PT. Sri Trang Lingga Palembang menggunakan algoritma program MatLab memberikan solusi khusus, selain proses ini mengurangi tenaga manusia yang digunakan dalam mengukur diameter indentasi dan menghitung kekerasan material, maka program mampu memberikan besarnya nilai kekerasan sehingga akan mengurangi lead time (rentang waktu pengerjaan) yang diperlukan untuk pengerjaan secara manual.

Peserta pelatihan sebanyak tujuh orang karyawan telah mengikuti teori dan praktikum prosedur pengujian kekerasan Brinnel dan melaksanakan pret-test dan post-test dengan tingkat kehadiran $80 \%$ dan rerata peningkatan hasil dari kedua test sebesar $42.57 \%$.

Tabel 1. Rangkaian Kegiatan Pengabdian

\begin{tabular}{|c|c|c|c|}
\hline No & Kegiatan Pengabdian & Lok: & \\
\hline 1 & Teori dasar sifat material suku cadang & \multirow{4}{*}{$\begin{array}{l}\text { Lab. Mekanik Teknik } \\
\text { Mesin dan PT. Sri } \\
\text { Trang Lingga } \\
\text { Palembang }\end{array}$} & \multirow{4}{*}{$\begin{array}{c}7 \text { Karyawan (Mechanic, drafter, } \\
\text { boiler section, PM section } \\
\text { Head, Otomotif, Man. FNC, } \\
\text { CS) \& Tim Pelaksana PKMSP }\end{array}$} \\
\hline 2 & Teori uji keker & & \\
\hline 3 & Ketrampilan uji & & \\
\hline 4 & Mengukur diameter indentasi & & \\
\hline
\end{tabular}




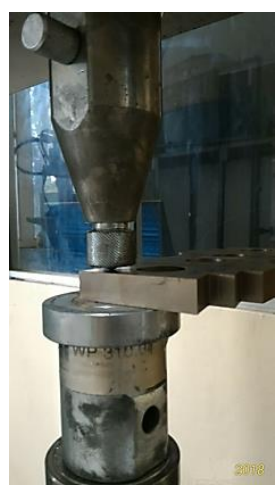

(a)

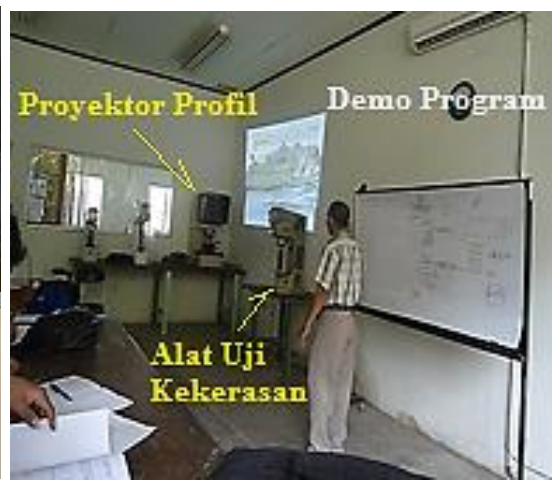

(b)

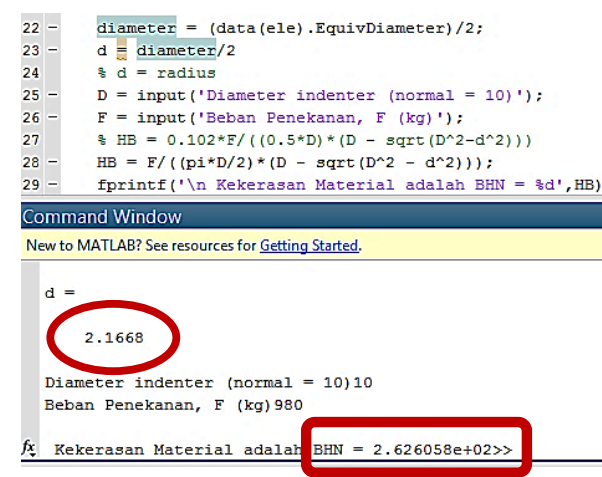

(c)

Gambar 2. (a) Proses Penekan Indentor (b) Pengukuran Indentasi dan (c) Skrip Program

Tabel 2. Hasil Uji Kompetensi Peserta PKMSP

\begin{tabular}{c|c|c|c|c|c}
\hline \multirow{2}{*}{ Peserta } & \multicolumn{2}{|c|}{ Skor Benar Uji Kompetensi } & \multicolumn{2}{c|}{ Prosentase (\%) } & \multirow{2}{*}{ Pemahaman/Ketuntasan } \\
\cline { 2 - 5 } & Pre-Test & Post-Test & Pre- & Post- & $\uparrow 25 \%$ \\
\hline 1 & 10 & 15 & 50 & 75 & $\uparrow 46 \%$ \\
\hline 2 & 11 & 16 & 55 & 80 & $\uparrow 56 \%$ \\
\hline 3 & 9 & 14 & 45 & 70 & $\uparrow 75 \%$ \\
\hline 4 & 8 & 14 & 40 & 70 & $\uparrow 21 \%$ \\
\hline 5 & 14 & 17 & 70 & 85 & $\uparrow 75 \%$ \\
\hline 6 & 8 & 14 & 40 & 70 & $\uparrow 100 \%$ \\
\hline 7 & 7 & 14 & 35 & 70 & $\uparrow 42,57 \%$ \\
\hline \multicolumn{7}{r}{} \\
\hline
\end{tabular}

\section{UCAPAN TERIMA KASIH}

Kegiatan Program Pengabdian Kepada Masyarakat Skim Penugasan (PKMSP) terlaksana dengan bantuan dana PNBP PolSri nomor kontrak: 9922/PL6.2.1/PM/2018 tanggal 22 November 2018 dan dana inkind PT. Sri Trang Lingga Palembang.

\section{REFERENSI}

Komvopoulos, K.2011, Mechanical Testing of Engineering Materials, pp. 13-26, Uniersity of California: Berkeley

Wahyuni, E. dkk., Uji Kekerasan Material dengan Metode Rockwell, Url:// web.unair.ac.id/admin/file/f_41124_UjiK ekerasanMaterialdenganMetodeRockwell. pdf, diakses pada 28 Oktober 2017
---, Material Testing: Laboratory Manual 2006, Istanbul Technical University: Faculty Of Mechanical Engineering

ASTM Standard E10-15, 2015, Standard Test Method for Brinell Hardness of Metallic Materials, ASTM International, West Conshohocken, PA, 2015, DOI: 10.1520/ E0010-15, www.astm.org

Surdia, T. dan Saito, S. 2005, Pengetahuan Bahan Teknik, Jakarta: Balai Pustaka

Hassanein, A. S. et al., 2015, A Survey on Hough Transform, Theory, Techniques and Applications, IJCSI International Journal of Computer Science Issues), Vol. 12, Issue 1, No 2, January 2015, pp. 139 156 